\title{
Placenta-Specific Gene 8 Protein
}

National Cancer Institute

\section{Source}

National Cancer Institute. Placenta-Specific Gene 8 Protein. NCI Thesaurus. Code C90307.

Placenta-specific gene 8 protein (115 aa, $\sim 13 \mathrm{kDa}$ ) is encoded by the human PLAC8 gene. This protein may be involved in dendritic cell activation. 